\title{
The Virtual Scientific Sessions from the American Society of Breast Surgeons During the COVID-19 Pandemic
}

\author{
Henry M. Kuerer, MD, PhD, FACS ${ }^{1,2}$, and Sarah L. Blair, MD ${ }^{1,2}$ \\ ${ }^{1}$ Division of Surgery, Department of Breast Surgical Oncology, The University of Texas MD Anderson Cancer Center, \\ Houston, TX; ${ }^{2}$ Department of General Surgery, University of California, San Diego, CA
}

Suddenly, the world entirely changed and everything we knew and were used to also had to change, including inperson national meetings. The pandemic did not allow for a safe 21st Annual Meeting of the American Society of Breast Surgeons to take place, scheduled for Las Vegas, Nevada. The one thing that did not change was the member drive for knowledge to advance breast care and decrease the burden of breast cancer for our patients all around the world. Another thing that did not change was the executive physician and staff leadership that rapidly turned our scientific sessions as oral presentations into the new normal of virtual meetings and allowed for presentation of the posters on our website. This historic year for our world and our society renewed our commitment to helping attendees elevate standard practice by improving the efficacy, safety, and quality of breast care for our patients and sharing the best of these advancements in this year's breast issue of the Annals of Surgical Oncology.

Much gratitude is given to the 33 members of the Publication Committee for careful review of 372 research abstracts for selection of the top studies for oral scientific, 'quick-shot', and poster presentations, and final review and selection of the highest impact publications for this issue of Annals of Surgical Oncology. Just some of the highlighted research studies published in this issue of Annals of Surgical Oncology include pivotal and essential work regarding enhanced patient recovery and decreasing the use

(C) Society of Surgical Oncology 2020

First Received: 13 July 2020

Accepted: 13 July 2020;

Published Online: 18 August 2020

H. M. Kuerer, MD, PhD, FACS

e-mail: hkuerer@mdanderson.org of opioid prescriptions for pain management after breast cancer surgery, ${ }^{1-4}$ understanding and further integration of neoadjuvant systemic (including hormonal) therapies to facilitate improved patient outcomes, ${ }^{5-9}$ and further elucidation and updates on breast reconstruction and standardizing oncoplastic surgery. ${ }^{10-14}$

The annual Outstanding Scientific Presentation Award for the best abstract presented by a resident, medical trainee, or fellow went to Dr. Daniel Lustig for his important work on development of a risk calculator to predict a low risk for malignancy upgrade when atypical ductal hyperplasia is diagnosed by image-guided biopsy, in order to identify patients most likely to benefit from surgical excisons..$^{15}$ The George Peter's Award for the best presentation by a fellow went to Dr. Britany Murphy for her work on emerging multi-gene panel testing and performance of contralateral prophylactic masectomy. ${ }^{16}$ These and other ASBrS articles published in this issue ${ }^{16-31}$ provide current research results germane to today's delivery of high-quality breast cancer care.

The pandemic is currently still active and the future ramifications of delayed and canceled screening, surgeries, and marked increases in neoadjuvant systemic therapy use for breast cancer will be evaluated in research studies for years to come. The impact on these dramatic changes in breast and other malignancies with respect to recurrence, survival, and emotional well-being will also be the subject of future research presentations at this society and others. In the final analysis, it is anticipated that there will be lessons learned and these practices will be incorporated into continuing enhanced standards in breast cancer care and global healthcare in general.

DISCLOSURES The authors declare no conflict of interest. 


\section{REFERENCES}

1. Moo T-A, Pawloski KR, Sevilimedu V, et al. Changing the default: a prospective study of reducing discharge opioid prescription after lumpectomy and sentinel node biopsy. Ann Surg Oncol. 2020. https://doi.org/10.1245/s10434-020-08886-9.

2. Morin C, Javid M, Patel Y, et al. Obese patients who receive an opioid-sparing enhanced recovery after surgery (ERAS) protocol are at increased risk of persistent pain after breast surgery. Ann Surg Oncol. 2020. https://doi.org/10.1245/s10434-020-08894-9.

3. Dinh KH, McAuliffe PF, Boisen M, et al. Post-operative nausea and analgesia following total mastectomy is improved after implementation of an enhanced recovery protocol. Ann Surg Oncol. 2020. https://doi.org/10.1245/s10434-020-08880-1.

4. Brenin DR, Dietz JR, Baima J, et al. Pain management in breast surgery: recommendations of a multi-disciplinary expert panel from the American Society of Breast Surgeons. Ann Surg Oncol. 2020. https://doi.org/10.1245/s10434-020-08892-x.

5. Davis J, Hoskin TL, Day CN, et al. Performance and clinical utility of models predicting eradication of nodal disease in patients with clinically node positive breast cancer treated with neoadjuvant chemotherapy by tumor biology. Ann Surg Oncol. 2020. https://doi.org/10.1245/s10434-020-08885-w.

6. Montagna G, Sevilimedu V, Jhaveri K, Morrow M, Pilewskie ML. How effective is neoadjuvant endocrine therapy (NET) in downstaging the axilla and achieving breast conserving surgery (BCS)? Ann Surg Oncol. 2020. https://doi.org/10.1245/s10434020-08888-7.

7. Crown A, Muhsen S, Zabor EC, et al. Does use of neoadjuvant chemotherapy affect the decision to pursue fertility preservation options in young women with breast cancer? Ann Surg Oncol. 2020. https://doi.org/10.1245/s10434-020-08883-y.

8. Piltin MA, Hoskin TL, Day CN, Davis J, Boughey JC. Oncologic outcomes of sentinel lymph node surgery after neoadjuvant chemotherapy for node positive breast cancer. Ann Surg Oncol. 2020. https://doi.org/10.1245/s10434-020-08900-0.

9. Laws A, Dillon K, Kelly BN, et al. Node-positive patients treated with neoadjuvant chemotherapy can be spared axillary lymph node dissection with wireless non-radioactive localizers. Ann Surg Oncol. 2020. https://doi.org/10.1245/s10434-020-08902-y.

10. Asaad M, Meaike J, Yonkus J, et al. Breast reconstruction in the setting of stage IV breast cancer: is it worthwhile? Ann Surg Oncol. 2020. https://doi.org/10.1245/s10434-020-08879-8.

11. Rizzi SKLA, Haddad CAS, Giron PS, et al. Early free range of motion upper limb exercises after mastectomy and immediate implant reconstruction are safe and beneficial: a randomized trial. Ann Surg Oncol. 2020. https://doi.org/10.1245/s10434-020-0888 2-z.

12. Braun SE, Dreicer M, Butterworth JA, Larson KE. Do nipple necrosis rates differ in pre-pectoral versus sub-muscular implantbased reconstruction after nipple sparing mastectomy? Ann Surg Oncol. 2020. https://doi.org/10.1245/s10434-020-08887-8.

13. Mandelbaum AD, Thompson CK, Attai DJ, et al. National trends in immediate breast reconstruction: an analysis of implant-based versus autologous reconstruction after mastectomy. Ann Surg Oncol. 2020. https://doi.org/10.1245/s10434-020-08903-x.

14. Lustig DB, Guo M, Liu C, et al. Development and prospective validation of a risk calculator that predicts a low risk cohort for atypical ductal hyperplasia upstaging to malignancy: evidence for a watch and wait strategy of a high-risk lesion. Ann Surg Oncol. 2020. https://doi.org/10.1245/s10434-020-08881-0.

15. Murphy BL, Yi M, Arun BK, Barrera AMG, Bedrosian I. Contralateral risk-reducing mastectomy in breast cancer patients who undergo multigene panel testing. Ann Surg Oncol. 2020. https://d oi.org/10.1245/s10434-020-08889-6.

16. Postlewait LM, Teshome M, DeSnyder SM, et al. Factors associated with pathological node negativity in inflammatory breast cancer: are there patients who may be candidates for a de-escalation of axillary surgery? Ann Surg Oncol. 2020. https://doi.org/ 10.1245/s10434-020-08891-y.

17. Shah C, Hobbs BP, Vicini F, et al. The diminishing impact of margin definitions and width on local recurrence rates following breast-conserving therapy for early-stage invasive cancer: a metaanalysis. Ann Surg Oncol. 2020. https://doi.org/10.1245/s10434020-08878-9.

18. Nanda AD, Mann MP, Cheng A-L, Moormeier J, Ahmadiyeh N. Impact of phone-call and access-enhancing intervention on mammography uptake among primary care patients at an urban safety-net hospital: a randomized-controlled study. Ann Surg Oncol. 2020. https://doi.org/10.1245/s10434-020-08884-x.

19. Rosenkranz KM, Ballman K, McCall L, et al. Cosmetic outcomes following breast-conservation surgery and radiation for multiple ipsilateral breast cancer: data from the Alliance Z11102 Study. Ann Surg Oncol. 2020. https://doi.org/10.1245/s10434-020-0889 3-w.

20. Chang JH, Abou-Zamzam A, Lee $\mathrm{S}$, et al. Has breast surgery shattered the glass ceiling? Trends in female representation at the American Society of Breast Surgeons Annual Meeting 2009-2019. Ann Surg Oncol. 2020. https://doi.org/10.1245/s104 34-020-08899-4.

21. Stafford A, Williams A, Edmiston K, et al. Axillary response in patients undergoing neoadjuvant endocrine treatment for node positive breast cancer-systematic literature review and NCDB analysis. Ann Surg Oncol. 2020. https://doi.org/10.1245/s10434020-08905-9.

22. Dauphine C, Moazzez A, Neal JC, Chlebowski RT, Ozao-Choy J. Single hormone receptor-positive breast cancers have distinct characteristics and survival. Ann Surg Oncol. 2020. https://doi. org/10.1245/s10434-020-08898-5.

23. Shaffer K, Cakmakoglu C, Schwarz GS, et al. Lymphedema prevention surgery: improved operating efficiency over time. Ann Surg Oncol. 2020. https://doi.org/10.1245/s10434-020-08890-z.

24. Findlay-Shirras L, Lima I, Smith, G, Clemons M, Arnaout A. Population trends in lobular carcinoma of the breast: the Ontario experience. Ann Surg Oncol. 2020. https://doi.org/10.1245/s104 34-020-08895-8.

25. Plichta JK, Ren Y, Marks CE, et al. Surgery for men with breast cancer: do the same data still apply? Ann Surg Oncol. 2020. h ttps://doi.org/10.1245/s10434-020-08901-z.

26. Partain N, Calvo C, Mokdad A, et al. Differences in re-excision rates for breast-conserving surgery using intraoperative $2 \mathrm{D}$ versus 3D tomosynthesis specimen radiograph. Ann Surg Oncol. 2020. h ttps://doi.org/10.1245/s10434-020-08877-w.

27. Amin AL, Fan F, Winblad OD, Larson KE, Wagner JL. Ipsilateral and concurrent breast cancer and atypical ductal hyperplasia: does atypia also need surgical excision? Ann Surg Oncol. 2020. h ttps://doi.org/10.1245/s10434-020-08896-7.

28. Nathanson SD, Leonard-Murali S, Burmeister C, Susick L, Baker P. Clinico-pathological evaluation of the potential anatomic pathways of systemic metastasis from primary breast cancer suggests an orderly spread through the regional lymph nodes. Ann Surg Oncol. 2020. https://doi.org/10.1245/s10434-020-08904-w.

29. Patel AR, Vuong B, Kuehner GE, et al. Adoption of opioidsparing and non-opioid regimens after breast surgery in a large, integrated health care delivery system. Ann Surg Oncol. 2020. h ttps://doi.org/10.1245/s10434-020-08897-6. 
30. Balci FL, Uras C, Feldman S. Clinical factors affecting the therapeutic efficacy of evening primrose oil on mastalgia. Ann Surg Oncol. 2020. https://doi.org/10.1245/s10434-020-08949-x.

31. Nayyar A, Strassle PD, Iles K, et al. Survival outcomes of earlystage hormone receptor positive breast cancer in elderly women. Ann Surg Oncol. 2020. https://doi.org/10.1245/s10434-020-0894 5-1.
Publisher's Note Springer Nature remains neutral with regard to jurisdictional claims in published maps and institutional affiliations. 